\title{
Tourism as a Method of "Soft Power" in Modern Diplomacy on the Example of the Russian Federation
}

\author{
Oleg A. Bunakov', Boris M. Eidelman¹, Liliya R. Fakhrutdinova', Niyaz K. Gabdrakhmanov ${ }^{1}$ \\ ${ }^{1}$ Kazan Federal University, Institute of Management, Economics and Finance \\ E-mail: nz99nz@yandex.ru mailto:nz99nz@yandex.ru,Contact: 89046626025
}

\section{Received: $21^{\text {st }}$ October 2017 Accepted: $16^{\text {th }}$ November 2017, Published: 31 ${ }^{\text {st }}$ December 2017}

\begin{abstract}
In this article authors describe formation of the concept "soft power" and its place in the modern world. Authors come to a conclusion that tourism is that element of "the soft power" which can promote more effective and competent positioning of Russia as benevolent country. Today the tourism industry is a key milestone of applying "the soft power" concept, plunging in particular countries, in particular cultures, in particular national life, the tourist recreates a true picture of the events in the state. Authors note that the Russian Federation needs creation abroad of positive image, for the purpose of applying the «the soft power» concept in the solution of diplomatic questions. In turn, tourism is one of the main methods of the «the soft power» concept and in any a case it is impossible to diminish a tourism role in permission of international issues. Development of the tourism industry promotes not only to increase in a tourist stream and attraction of investments, but also allows creating a positive image of the country and its subjects in the opinion of foreign tourists. Investigating value of the «the soft power» concept, authors came to a conclusion that tourism represents a secret platform for realization of national and public interests on the international scene.

Tourism as a method of "the soft power" in modern diplomacy is, first of all, the tool by means of which the state will be able to tell about itself to the world.
\end{abstract}

Keywords: Tourism, Sustainable Development, "Soft Power".

\section{Introduction}

By Joseph Nye's definition, "the soft power" assumes achievement of necessary results due to formation of own attractive image and voluntary will of other participants [1].

Today the tourism industry is a key milestone of applying the «the soft power» concept, plunging in particular the countries, in particular cultures, in particular national life, the tourist recreates a true picture of the events in the state. Sometimes, this picture of the events is various with the picture created by mass media. Russia is a many-sided country with a huge tourist potential which is important for positioning correctly on the international scene. Importance of the correct positioning of image of the country in 2012 was sounded by Vladimir Vladimirovich Putin at the Meeting of ambassadors. At the moment, large-scale work in this direction is developed: brands of tourist subjects are created, large sporting international events, such as the Winter Olympic Games in Sochi and the Universiade in Kazan, etc. are held.

The Russian Federation needs creation abroad of positive image, for the solution of diplomatic questions. In turn, tourism is one of the main methods of the «the soft power» concept and in any a case it is impossible to diminish a tourism role in permission of international issues. Development of the tourism industry promotes not only to increase in a tourist stream and attraction of investments, but also allows creating a positive image of the country and its subjects in the opinion of foreign tourists.

\footnotetext{
Results and Discussion

For the first time the term "soft power" described in the book "Leadership limits: change of the nature of the American power" the American political scientist, professor of Harvard University Joseph Nye in 1990. Nye considered that "the soft power" is an ability of one country to influence the choice and will of other countries, by means of formation of an attractive image in their eyes. At first sight, this definition looks strange, however this certain innuendo and inaccuracy created all concept of the created theory.

Joseph Nye, during creation of the idea of the «the soft power» concept, proceeded from the rich practical experience. For operating time in law enforcement agencies of the USA, and also during professorial activity, he managed to become one of the best experts in the sphere of the international relations.

Later the scientist characterized the concept "force" more accurately. Force is an ability to change behavior of others, for receiving what you wish. There are several ways of achievement of the desirable (several forces): coercion (military force), payment (economic force) and attractiveness ("soft power").
} 
Professor Joseph Nye repeatedly came back to development of the idea. And though, the theory of "the soft power" quickly gained popularity in the sphere of the international relations, but the main problem consisted in its wide meaning. J. Nye was forced to write the letter to Foreign Policy magazine in 2006. In this letter professor emphasized that in Russia and in China "soft" force is misunderstood, exactly, as a promotion analog though the essence of "the soft power" is much broader. The «the soft power» concept consists in creation of not forcing positive image which is perceived as charming and pleasant. Later, by consideration of value of the term "soft power" J. Nye wrote that the best promotion is not promotion. Trust the scarcest resource [2]. However, it should be noted that the trust provided by means of special tools of foreign policy does not assume reciprocity, and demands creation of trust from an object, but not the subject of "the soft power".

The terminological problem of definition "the soft power" consists in discrepancy of translation into Russian. Many Russian scientists suggest using the concept "soft power", than "force" as the term "power" defines the concept created J. Nye more precisely. But the steady «the soft power» concept already entered the international lexical traffic of diplomacy, and the terms "power" and "force" are included into one synonymic row.

It should be noted close interrelation of "soft" and "rigid" forces as implementation of the «the soft power» concept in an ultimate goal means transformation of appeal into influence. Thereby, it is possible to draw a conclusion that it is possible to reach influence smaller costs, than in case of use of "the rigid force".

But, often, "the soft power" of the state with a powerful "rigid force" is not always perceived with great attention, quite often strength frightens weaker, "the soft power" of this state can inspire mistrust, fear and fear. This phenomenon has a reverse side: to the states with high military potential it is chained big degree of attention of the international public, and implementation of the «the soft power» concept can attract the greatest interest and appeal.

Quite right the Russian foreign affairs specialist Alexey Fonenko about a complementarity of "the soft power" in relation to "rigid" noted, but also it should be noted, about his prevention that "the soft power" will hardly be able to attract the former enemies on your party, but in too time it will show doubting whose it is necessary to side.

Later Joseph Nye continued to develop this concept in the book "Soft power. How to achieve success in world politics" which was published in 2004.
According to J. Nye's theory in the world force extends by the principle of a difficult three-level game in chess. At the top level of a chessboard there is a military power, at the average level the economic force which, for many years, represents the multipolar world with strong players settles down. At the third level the international relations in the modern global world in which the predominating role is played by the nongovernmental organizations which are active for the purpose of creation of an attractive image of the country settle down. Strengthening of positions of the country at the third level of a chess game is given to strengthening of positions at the international level [3]. During applying the «the soft power» concept information image which allows people, recipients of this information is created, to create a certain image apprehended at the psychological level. "The soft power" creates certain stereotypes which influence perception of this or that political action subsequently. Sometimes these stereotypes are far from reality, people do not interact directly with subject to applying the concept. Thanks to it the «the soft power» concept influences all spheres of private and public life becomes one of elements of the general and political culture.

Among the used instruments of implementation of the «the soft power» concept those which rely on the first levels of a pyramid of Maslow are most effective: need for safety, protection of family values, etc.

The «the soft power» concept uses "virus" information which is broadcast through the leading mass media, social networks and other news communications. Content of "the soft power" creates and broadcasts certain images, stereotypes and values which exert a certain impact on an object, also content can rely on historical memory of target audience. During realization of methods of "the soft power" all methods of broadcast of information which will be able to attract interest of the person which will extend these ideas in masses subsequently are used. The main tasks of such information influence - to create mood, to raise doubts, to lay the foundation for a thought for change of the relation to an object.

The «the soft power» concept cannot be used as a constant method of effective maintaining the international relations as she creates only a platform, for permission of political affairs, but does not solve them. An object of "the soft power" is understood as the region or the state to whom not power influence is directed.

The main mission of the «the soft power» concept consists in creation of an attractive image of the state among the population and separate political elite of the foreign states. A striking example of effective 
implementation of the «the soft power» concept, the international policy of the United States of America is. The created image of appeal of the American way of life, the American policy and the American culture, not one decade, attract the population of the foreign states.

According to Joseph Nye's concept, in the USA there are several pillars of "the soft power" which provide external appeal of the country.

The first pillar of applying the «the soft power» concept is an appeal of the American way of life and culture. Joseph Nye specifies in the book "Soft power. How to achieve success in world politics" criteria of leadership of the USA: the number of emigrants, popularity of the American music, popularity of cinema, volume of teleproduction broadcast abroad [4].

The second pillar of "the soft power" of the USA is the American political ideology which causes approval in many countries of the world. In understanding of most of experts in the sphere of the international relations, fundamental values of the USA, today, it is liberal democracy and market economy, this ideological complex is tried to be extended to other countries, by implementation of the «the soft power» concept. During implementation of this concept, U.S. authorities do not impose by force this mechanism of development of the state, and create an attractive image of alternative development. According to professor it is necessary to pay more attention to any development of exchange programs which are designed to show true non-material values of the American culture. Also it is necessary to involve actively mass media where it is possible to create necessary image and to promote increase in loyalty to the country [5].

According to the theory which is put forward by Joseph Nye, a fundamental basis of "the soft power" is everyday laborious work "on places", directed to forming of the strong confidential relations. Professor places particular emphasis for work of the nongovernmental organizations created for lobbying of interests of the state abroad. Nye, considers that "beginning from Hollywood and to the higher education, civil society does more for representation of the USA to other people, than it does the government. Hollywood often represents consumer society and violence, but it also advances values of individualism, social mobility and freedom (including freedoms for women). These values do America attractive in the opinion of many people abroad" [6].

An exclusive role in the concept of Nye is played by information communications. Joseph Nye describes communication between approach of information era and origin of the «the soft power» concept as "practical tool in world politics". Professor considers that success of the theory consists in distribution in information space of the main methods.

The listed levers of "the soft power", according to professor Nye are higher and higher, have to create own appeal of the United States of America based on such doctrines as openness of the power, personal liberty, political culture of society, availability of education.

From the practical point of view, deep understanding of an essence of "the soft power" in the concept of professor Nye allocation of such aspect of relative force as an opportunity to exert impact on interests of third parties is, thereby they will involuntarily want most too, as it is necessary for us, need to someone something respectively will disappear to order.

It should be noted that along with positive properties of the «the soft power» concept it is necessary to understand the maximum range of its application. Specialists foreign affairs specialists place emphasis that implementation of the «the soft power» concept can, in some situations, not only help the state, but also do much harm to it, especially when capacity-building of "the soft power" pushes need of development of "the rigid force" the background.

The «the soft power» concept formulated by Professor Joseph Nye despite the popularity in international policy, has a large number of critics.

In the modern scientific world, the theory of "the soft power" is submitted authors as the tool by means of which favorable political decisions are made. J. Gallarotti considers that similar understanding of the «the soft power» concept is very similar to A. Garamsha's concept "about hegemony" and theories of "the third party of the power" of S. Luce's [7]. All this forms one more, often criticized, the basis of "the soft power" - false consciousness. Use of this argument assumes that false consciousness is implicitly formed by one dominating nation at other subordinate. In the ideas of the neoliberal theory of "the soft power" it is supposed that "the soft power" gives the choice of ideologies to that to whom it is directed. An object of "the soft power" has to choose only the most acceptable ideology and the complementary ally. Often practice shows that this idealistic pictures it is impossible as decision-making of an object of "the soft power" happens or authoritative, or is based on a delusion. Summing up the result of the aforesaid, it is possible to note that "the soft power" is a peculiar manipulator and substantially can promote domination.

Further it is important to distinguish the terms "force" and "domination". The first assumes mutual the benefit but which is not based on equality, domination comes at the time of crossing of different interests, and also assumes submission by one another. J. Gallarotti 
considers that the «the soft power» concept is crossed with the theory of M. Foucault at the heart of which the same conflict of interests is put. According to Gallarotti, specifics of "the soft power" consist in ability of the pre-potent nation to give the interests for interests of the countries on which there is an influence. Gallarotti writes: "Tendency of great or pre-potent powers to intensively make investments in creation of the modes and the international organizations forces to believe that such leverage is really important for these nations. The fact that such institutes are supported by the nations allocated with bigger independence induces to consider that all of them still serve a number of the purposes in interests of the pre-potent nations: law enforcement, protection of reputation, a protection from hindrances by what the unilaterality, various ways of simplification of functioning of the markets is accompanied. Besides, as these institutes are arranged in a big way and are supported by the powerful nations, they often perform additional functions for the benefit of the nations. But as institutes accept more multilateral power structure, often their functions can deviate interests of those powerful nations which created them" [8].

Other important reflection of the «the soft power» concept is the Chinese school of studying of this phenomenon. Since 2003 the leadership of the People's Republic of China was engaged in development of the strategy proving the place of China in the modern world. According to a research of scientists O. Borokh and A. Lomanova, the Chinese ideology of external presence underwent transformation from model of "peaceful development" and "a peace eminence" to model "" the harmonious world of joint prosperity", offered Hu Jintao. Yukepin put forward the idea of "the harmonious world" based on aspiration to creation of the valuable ideal based on development and harmony of the world.

\section{Conclusion}

Leaning on everything aforesaid, it is possible to draw a conclusion that one of bright and effective methods of "the soft power" is tourism which represents a secret platform for realization of national and public interests on the international scene. Tourism as a method of "the soft power" in modern diplomacy is, first of all, the tool by means of which the state will be able to tell about itself to the world.

\section{Acknowledgements}

The work is performed according to the Russian Government Program of Competitive Growth of Kazan Federal University.

\section{References}

[1] Nye Joseph S. Bound to Lead: The Changing Nature of American Power. N.Y.: Basic Books; 1990, p. 153-171.

[2] Filimonov GY. Topical issues of formation of strategy of "the soft power" in foreign policy of the Russian Federation. The Geopolitical magazine; 2013. № 1 .

[3] Cherevichko TV. Turizm as instrument of public diplomacy. History. Mezhdunarodnye otnosheniya; 2014, No. 4.

[4] Nye, Joseph. Soft Power. The Means to Success in World Politics. NY: Public Affairs; 2004.

[5] Bunakov O.A., Zaitseva N.A., Larionova A.A., Suslova I.A. Improoving the training system as a basis for improved management of sustainable development of tourism. Pp. 275-283.

[6] Nye, Joseph S. Think Again: Soft Power. Foreign Policy; 2006. February, 23.

[7] Bunakov O.A. Development of tourism in the region on the basis of cluster approach. Pp. 5104-5106.

[8] Eidelman B. M. and Fakhrutdinova. L. R. Improving of Using of Advertising Technology in Tourism. International Business Management, Vol: 10, Issue: 21, 2016, pp. 5086-5088.

[9] Bunakov, O.A., Rubtzov, V.A. Complexity of positioning in tourism as the basis of its sustainable development. International Business Management; 2016, 10 (21), pp. 5101-5103.

[10] Bunakov, O.A., Zaitseva, N.A., Larionova, A.A., Chudnovskiy, A.D., Zhukova, M.A., Zhukov, V.A. Research on the evolution of management concepts of sustainable tourism and hospitality development in the regions. Journal of Sustainable Development, 2015, 8 (6), pp. 39-44.

[11] Gabdrakhmanov N.K, Rubtzov V.A, Baybakov E.E, Tourism and sustainable development. Academy of Strategic Management Journal; 2016, Vol.15, Special Issue 1, pp.21-26. 